\title{
Markups and Contribution Margins of Nursing Homes
}

\author{
Ecler Jaqua MD ${ }^{1 *}$, Terry Jaqua PhD, MBA ${ }^{2}$ \\ ${ }^{1}$ Trident University International - Business Administration Department, USA. \\ ${ }^{2}$ Trident University International - Health Sciences Department, USA.
}

*Corresponding Author: Ecler Jaqua, Trident University International - Business Administration Department, USA.

Received Date: September 03, 2021 | Accepted Date: September 22, 2021 | Published Date: September 30, 2021

Citation: E Jaqua, T Jaqua. (2021). Markups and Contribution Margins of Nursing Homes. International Journal of Clinical Case Reports and Reviews. 8(4); DOI:10.31579/2690-4861/171

Copyright: () 2021 Ecler Jaqua, This is an open-access article distributed under the terms of the Creative Commons Attribution License, which permits unrestricted use, distribution, and reproduction in any medium, provided the original author and source are credited.

\begin{abstract}
Markups and profit margins are different accounting terms that analyze similar transactions and use the same inputs but show additional information. The two use costs and revenues as in their calculations. The critical difference is that while profit margins refer to sales less the cost of goods sold, markups refer to the amount that needs to be added to the cost of goods to get to the final selling price. Understanding these two terms ensures that price setting is done correctly. Too low or high price setting may cause lost profits or sales. Also, with time, the price setting of a firm impacts its market share. This research paper discusses markups and contribution margins of nursing homes.
\end{abstract}

Keywords: Nursing Homes; markups; Rehabilitation services; medical care

\section{Industry Description}

Nursing homes are also known as skilled nursing facilities. They offer various personal and health care services. The services in a nursing home focus more on medical care. The multiple services in these facilities include 24-hour supervision, nursing care, constant assistance with daily activities, and providing three meals a day. Rehabilitation services are also available. Such include speech, occupational, and physical therapy. Some people opt to stay at a skilled nursing facility after their discharge from the hospital (Yang et al., 2021). They go home after their recovery. However, many nursing home residents choose to live there permanently. Many have ongoing mental or physical conditions requiring constant supervision and care.

A skilled nursing facility has the best care for older adults. They offer custodial care, giving help getting out of bed, assisting individuals with bathing, feeding, and dressing. Also, they provide high levels of medical care. A licensed physician is supervising the patients. Some medical professionals are always on the premises. Other medical professionals, including physical or occupational therapists, are available (Yang et al., 2021). Due to the aging population, many individuals are faced with the prospect of moving their older family members into convalescent or a nursing home. It is a decision that may arrive suddenly following hospitalization. Such decisions come as it becomes more challenging to meet the aging family member's needs.

The Margins and Markups on Services in Nursing Homes
The nursing home in the United States is both For-profit and

non-profit facilities. For-profit facilities are operated and run by businesses and corporations, and shareholders control them. Such facilities prioritize shareholders and put the needs of their residents second. The conflict of interest reduces the quality of care offered to residents. In addition, there is the pressure of keeping the staffing levels. On the other hand, non-profit facilities prioritize residents' quality of care since they have no responsibility to the shareholders. Such tend to higherquality and more staff.

There are also fewer bedsores, lower restraints, and government-cited deficiencies. The majority of nursing homes in the United States (about 70\%) are for-profit, and this trend continues to grow. It means that their prime role is profit maximization. The expenses and revenues of a nursing home are linked to its value strategy. The highest value is created when a nursing home delivers quality care and sets low prices (Yang et al., 2021). At face value, the strategy may appear to be at odds with the goal of profit maximization; thus, it may lead to low profitability.

A low price-setting would seem to depress the facility's total revenues. But the low price and high-quality care attract more residents, the revenues and profits are expected to increase. On the side of expenses, uncertainty exists due to the high quality- low price strategy. The uncertainty is whether the high quality is more costly to produce than the low quality of care. In case the high quality is expensive, then there is likely to be pressure on profits. However, if patient safety errors and 
complications are avoided, expenses may be lower. Also, the majority of nursing homes depend on Medicare and Medicaid revenues.

\section{Other Economic Factors that Affect the Markups in Nursing Homes}

Other economic factors that affect markup in nursing homes include demand and competition. High demand for nursing home care leads to cost reduction by these facilities in their efforts to maximize profits. Price setting when the demand is high is unconstrained by the need to attract more residents. Due to the high demand, quality of care is also not a priority in these facilities. The presence of competition is likely to prevent organizations, including nursing homes, from reducing costs to the point that may curtail quality.

If there is competition, consumers who value quality are more likely to consider services from other firms with better quality (Lord et al., 2018). Thus, in such a situation, firms will set prices that attract most customers from their competitors. But, if the demand for the services is high, the competition needed to counterbalance cost-minimization incentives is diminished. There is always a readily available surplus of potential residents. In this case, nursing home facilities can reduce quality and costs with impunity since the danger of prospective residents' losses is minimal.

\section{Marketing Techniques that Companies Can Use to Support their Pricing Schemes}

Nursing homes can use high-margin strategies to support their pricing schemes. Skimming and premium pricing are two strategies that the facilities can use to emphasize profit maximization. Skimming is a pricing strategy whose objective is short-term profit maximization. It involves setting high price points at the initial stages and then lowering the prices after achieving high-profit margins. Premium pricing enables business owners to align their price points with superior service benefits and quality brand image. Thus, it helps in achieving long-term profit margins (De Toni et al., 2017). It is a pricing strategy that involves establishing price points at the industry top to match a luxury, high-end brand imagemany customers associate price with quality. Therefore, marketing your service as the best quality means that you attract many luxurious and highclass customers. Many consumers will pay if they see the quality promised.

\section{Conclusion}

Nursing homes offer various personal and health care services, focusing more on medical care. Many of the nursing homes in the United States are for-profit, meaning that their prime role is profit maximization. The expenses and revenues of a nursing home are linked to its value strategy. The highest value is created when a nursing home delivers quality care and sets low prices. Competition and demand are other economic factors that affect markup in nursing homes. Some market technique strategies that nursing homes can use to support their pricing schemes include skimming and premium pricing.

\section{Conflict of Interests}

With the submission of this manuscript, I would like to undertake that:

- $\quad$ All authors of this research paper have directly participated in the planning, execution \& analysis of this study.

- $\quad$ All authors of this paper have read and approved the final version submitted.

- The content of this manuscript has not been copyrighted or published previously.

- The content of this manuscript is not under consideration for publication elsewhere.

- The content of this manuscript will not be copyrighted, submitted, or published elsewhere, while acceptance by the journal is under consideration.

- There are no directly related manuscripts published or unpublished by any authors of this paper.

This manuscript wasn't partially or fully sponsored by any agency, and it was self-supported.

\section{References}

1. De Toni, D., Milan, G. S., Saciloto, E. B., \& Larentis, F. (2017). Pricing strategies and levels and their impact on corporate profitability. Revista de Administração (São Paulo), 52, 120 133.

2. Lord, J., Davlyatov, G., Thomas, K. S., Hyer, K., \& WeechMaldonado, R. (2018). The role of assisted living capacity on nursing home financial performance. INQUIRY: The Journal of Health Care Organization, Provision, and Financing, 55, 0046958018793285.

3. Yang, O., Yong, J., \& Scott, A. (2021). Nursing Home Competition, Prices and Quality: A Scoping Review and Policy Lessons. The Gerontologist.

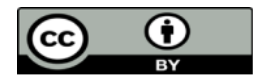

This work is licensed under Creative Commons Attribution 4.0 License

\section{To Submit Your Article Click Here: Submit Manuscript}

DOI: $10.31579 / 2690-4861 / 171$

\author{
Ready to submit your research? Choose Auctores and benefit from: \\ $>$ fast, convenient online submission \\ $>$ rigorous peer review by experienced research in your field \\ $>$ rapid publication on acceptance \\ $>$ authors retain copyrights \\ $>$ unique DOI for all articles \\ $>$ immediate, unrestricted online access
}

At Auctores, research is always in progress.

Learn more auctoresonline.org/journals/international-journal-of-clinicalcase-reports-and-reviews- 